\title{
CAMTA1 Transcription Factor Regulates Salinity And Drought Tolerance In Chickpea (Cicer arietinum L.)
}

\section{Ms. Meenakshi}

CSIR-National Botanical Research Institute

\section{Anil Kumar}

CSIR-National Botanical Research Institute

\section{Varun Kumar}

CSIR-National Botanical Research Institute

Arvind Kumar Dubey

CSIR-National Botanical Research Institute

\section{Shiv Narayan}

CSIR-National Botanical Research Institute

\section{Samir V. Sawant}

CSIR-National Botanical Research Institute

Veena Pande

Kumaun University

\section{Pramod Arvind Shirke}

CSIR-National Botanical Research Institute Indraneel Sanyal ( $\sim$ i.sanyal@nbri.res.in )

National Botanical Research Institute CSIR https://orcid.org/0000-0002-2592-773X

\section{Research Article}

Keywords: CAMTA, Cicer arietinum (L.), Agrobacterium-mediated transformation, Drought, Antioxidants

Posted Date: September 3rd, 2021

DOI: https://doi.org/10.21203/rs.3.rs-840327/v1

License: (c) (1) This work is licensed under a Creative Commons Attribution 4.0 International License. Read Full License 


\section{Abstract}

Various abiotic stresses like drought, salinity, high temperature, and chilling adversely affect plant growth and productivity. Terminal drought stress is one of the major concerns which limits the growth and yield of chickpea. CAMTA (Calmodulin binding transcription activator) plays a vital role in stress tolerance in plants. In this study, we have selected a CAMTA1 gene to explore its role against salinity and drought stress in an economically important crop, chickpea (Cicer arietinum L.). CAMTA1 gene was then overexpressed in chickpea and was exposed to drought and salinity. The over-expression of CAMTA1 enhanced the activities of various antioxidant enzymes (ascorbate peroxidase; APX, catalase: CAT, glutathione S-transferase; GST, superoxide dismutase; SOD, monodehydroascorbate reductase; MDHAR). The reduced stress markers TBARS and $\mathrm{H}_{2} \mathrm{O}_{2}$ enhanced the survival of plants against both stresses. The physiological parameters (net photosynthesis; $P_{\mathrm{N}}$, transpiration; $E$, stomatal conductance; $g_{\mathrm{S}}$ photochemical quenching; $q \mathrm{P}$, non-photochemical quenching; $q \mathrm{~N}$, and electron transport rate; ETR) were improved in the transgenics under both the stresses, that protected the plants from damage. This investigation verified that the CAMTA1 gene provides tolerance against drought and salinity by maintaining biochemical, physiological, and morphological performances, and could be exploited for genetic engineering strategies to overcome the stresses in other economically important crops.

\section{Introduction}

Chickpea (Cicer arietinum L.) ranks second in area and third in the production among food legumes and is a good source of protein for humans. It is the most common grain legume in 40 countries worldwide, including arid and semi-arid regions (Rao et al. 2002). Water deficit is one of the significant constraints for the reduction in crop yield. Plants respond to drought stress and acclimatize through various physiological and biological changes.

Various environmental factors affect plants, such as biotic and abiotic stress. Abiotic stress includes salinity, chilling, drought, heat stress, and temperature. Drought stress is one of the major constrains for the reduction in crop yield and productivity. It occurs when the available water in the soil is reduced, and atmospheric conditions cause a considerable loss of water by evapo-transpiration. Drought tolerance is seen in almost all plants, but it varies from species to species (Jaleel et al. 2007). It reduces plant growth by affecting various physiological and biochemical processes such as photosynthesis, respiration, translocation, ion uptake, carbohydrates, and nutrient metabolism (Farooq et al. 2009). Terminal drought (soil moisture stress that occurs at the crop's pod filling and seed development stage, with increasing severity at the end of the season) is a major constrain to chickpea production during the closing stages of its reproductive phase (Gaur et al. 2008). It affects both elongation and expansion growth (Anjum et al. 2003a). Plants have different mechanisms to adapt under water stress conditions, including drought escape, drought avoidance. Due to terminal drought, plants lose their ability to survive and decrease crop yield and productivity. Several transcription factors have been revealed in plants, having crucial roles during plant growth, development, and under various stresses. 
Transcription factors regulated by calcium $\left(\mathrm{Ca}^{2+}\right)$, which act as a secondary messenger, play a vital role in several signaling pathways of growth and development as well as in stress signaling and adaptation. Calmodulin (CaM) is one of the prominent $\mathrm{Ca}^{2+}$ sensors in eukaryotic cells, including plants. During calcium signaling, stimulus-response involves a set of $\mathrm{Ca}^{2+}$ sensor proteins and $\mathrm{Ca}^{2+}$ binding proteins (Galon et al. 2010). Three major types of calcium sensor proteins are calmodulin (CaM) like proteins (CMLs), calcium-dependent protein kinases (CDPKs), and calcineurin B-like proteins (CBLs) (Poovaiah et al. 2013). When there is an increase in the intracellular $\mathrm{Ca}^{2+}$, calmodulin (CaM) interacting with calcium undergoes a conformational change, thus activates the target gene and other stress-responsive genes. Hence, to explore the role of the CAMTA1 gene under drought stress, a TF named CAMTA (Calmodulin binding transcription activator) was expressed in chickpea. CAMTA is composed of multiple functional domains, including nuclear localization signal (NLS), a CG-1 DNA binding domain which includes CGCG and CGTG motif, TIG domain which is an immunoglobulin-like fold involved in non-specific DNA binding, ANK repeat, which helps in protein-protein interaction, and a varying number of IQ motifs in a conserved manner. The previous report identified the family of six Arabidopsis genes encoding calmodulin-binding transcription activator (CAMTAs), also referred to as signal responsive protein (SRs) or ethylene-induced CaM binding proteins (EICBP).

In this study, we have chosen the CAMTA1 gene based on their protective role against drought, as revealed in Arabidopsis thaliana (Pandey et al. 2013), and we have further explored its protective role against salinity and drought stress in an economically important crop chickpea. We have successfully transformed the CAMTA1 gene in chickpea and validated the CAMTA1 gene in chickpea and determined its possible role against drought stress. The expression of CAMTA1 was found to be elevated in all transgenic lines during qRT-PCR analysis. Several stress-responsive biochemical and physiological performances were estimated to explore the role of CAMTA1 in drought stress, and enhancement was found in most of the parameters evaluated that validated that over-expression of CAMTA1 significantly enhanced drought tolerance in chickpea.

\section{Materials And Methods}

\subsection{Plant material and experimental design}

Chickpea cultivars of P-362 were obtained from Gobind Ballabh Pant University, Pantnagar, Uttarakhand. The seeds were surface sterilized with mercuric chloride $(0.1 \%, \mathrm{w} / \mathrm{v})$ for $5 \mathrm{~min}$ followed by washing with sterile distilled water, and then with $70 \%$ ethanol for $3 \mathrm{~min}$ followed by washing with sterile distilled water. Seeds were kept overnight for imbibition, and the water was removed the next day. The seeds were then allowed to germinate in the dark for 2-3 days. The germinated seedling was placed in Murashige and Skoog's (MS) salts containing B5 vitamins, sucrose (3\% w/v), and agar $(0.8 \% \mathrm{w} / \mathrm{v})$ adjusted to $\mathrm{pH} 5.8$. The medium was autoclaved at $121 \mathrm{psi}$ for $20 \mathrm{~min}$. The culture was incubated in the culture room under

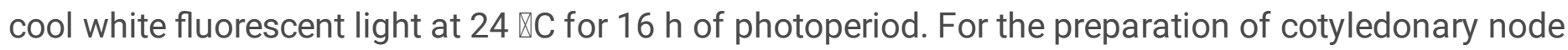
explants (CNs), the cotyledons and axillary shoots were removed from 17 days old seedlings. 


\subsection{Construct preparation and plant transformation}

CAMTA1 gene was cloned in PCAMBIA 1301 plant expression vector. This vector consists of hygromycin (hptll) selection marker (plant) and kanamycin selection marker (bacterial). The CAMTA1 gene was cloned in the PCAMBIA 1301 vector and was followed by plasmid isolation. Restriction digestion was performed with two restriction enzymes $B g / l l$ and BstEll. The presence of insertion of the CAMTA1 gene was confirmed by gel electrophoresis (Supplementary Fig. S1).

\subsection{Agrobacterium strain and plasmid}

Agrobacterium strain LBA4404 was used for transforming the binary expression vector pCAMBIA1301. YEB medium was prepared by adding appropriate antibiotics (Kanamycin $50 \mathrm{mg} / \mathrm{l}$, Streptomycin $50 \mathrm{mg} / \mathrm{l}$, and Rifampicin $20 \mathrm{mg} / \mathrm{l}$ ) and grown overnight at $28 \otimes C$ and was harvested by centrifugation at 4,000 rpm and the pellet was re-suspended in $25 \mathrm{ml}$ of MS medium containing $100 \mu \mathrm{M}$ acetosyringone. O.D. of the culture was between 0.8 to 1.0 at $600 \mathrm{~nm}$. Excised nodes were sonicated for $30 \mathrm{sec}$ and then incubated

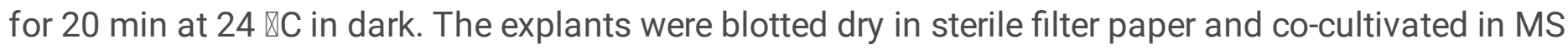
medium plates containing BAP and $100 \mu \mathrm{M}$ acetosyringone for $48 \mathrm{~h}$ under normal growth conditions. The explants were then transferred to MS medium containing cefotaxime $(500 \mathrm{mg} / \mathrm{l})$ and incubated for 7 days under $16 / 8 \mathrm{~h} \mathrm{L/D} \mathrm{cycle.}$

\subsection{Selection and regeneration}

The regenerated shoots were transferred to MS medium containing hygromycin for the selection of transformed cells. Different concentrations of hygromycin $\left(5,10\right.$, and $\left.15 \mathrm{mg} \mathrm{I}^{-1}\right)$ were used. After three subsequent selections, the surviving shoots were transferred to a regeneration medium containing (Zeatin $0.02 \mathrm{mg} / \mathrm{l}$, Silver nitrate $17 \mathrm{mg} / \mathrm{l}$, and Chlorocholine chloride $0.2 \mathrm{mg} / \mathrm{l}$ ). Seeds were grown in a cup filled with soilrite for 14 days and used for grafting. After 14 days, the shoots were grafted onto the germinated seedlings and transferred to the plant growth chamber (Adaptis 1000 PG, Conviron, Canada). The plants were transferred to the glasshouse for hardening and acclimatization and subsequent flower development and pod setting (Supplementary Fig. S2).

\subsection{Gene expression analysis of chickpea by qRT-PCR}

To analyze gene expression, total RNA was isolated from the leaves of chickpea plants and control plants, using Spectrum plant total RNA kit (Sigma-Aldrich, USA). cDNA was prepared using RevertAid First Strand cDNA Synthesis Kit (Thermo Scientific, USA). This cDNA was used as a template for the quantification of total transcript using 2x Mastermix SYBR green dye (Thermo Scientific, USA) in a 7500 real-time PCR machine (Applied Biosystems, USA). The chickpea actin gene was used as a reference control. The relative expression of the gene was analyzed and calculated using the $2^{\wedge \wedge} \mathrm{C}_{\mathrm{T}}$ method (Livak and Schmittgen. 2001).

\subsection{Biochemical analysis of transgenic chickpea under drought and salinity stress}


Total protein was extracted from the chickpea leaves by using the Total Protein Extraction Kit (Merck, Germany) and was quantified with the Bradford method (1976) at $595 \mathrm{~nm}$ (Spectramax 340 PC, Molecular Devices, USA). For the analysis of enzyme activities, fresh leaves of chickpea (200 $\mathrm{mg})$ were crushed in liquid $\mathrm{N}_{2}$, and the extract was prepared with $2 \mathrm{ml}$ of $100 \mathrm{mM}$ phosphate buffer $(\mathrm{pH} 7.5)$ having

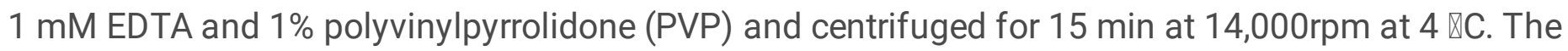
resultant supernatant was used for the assay of different enzymes.

To estimate SOD (EC 1.15.1.1) activity in chickpea, $1 \mathrm{ml}$ of enzyme extract was prerpared according to Beauchamp and Fridovich (1971). The absorbance of the reaction mixture was measured at $560 \mathrm{~nm}$, where 1 unit of SOD activity is defined as the amount of enzyme required to cause $50 \%$ inhibition of the nitro blue tetrazolium (NBT) reduction in the light.

The estimation of $\mathrm{H}_{2} \mathrm{O}_{2}$ was also performed and measured spectrophotometrically after a reaction with potassium iodide $(\mathrm{KI})$. The reaction mixture consisted of $0.5 \mathrm{ml} 0.1 \%$ trichloroacetic acid (TCA) leaf extract supernatant, $0.5 \mathrm{ml}$ of $100 \mathrm{mM}$ potassium phosphate buffer, and $2 \mathrm{ml}$ reagent $(1 \mathrm{M} \mathrm{KI} \mathrm{w} / \mathrm{v}$ in Milli$\mathrm{Q}$ water). The reaction was developed for $1 \mathrm{~h}$ in darkness, and absorbance was measured at $390 \mathrm{~nm}$. The amount of hydrogen peroxide was calculated using a standard curve prepared with a known concentration of $\mathrm{H}_{2} \mathrm{O}_{2}$.

The method of Nakano and Asada (1981) was used to estimate APX (EC 1.11.1.11) activity in chickpea. The reaction mixture consists of $1.0 \mathrm{ml}$ of reaction buffer potassium phosphate $(\mathrm{pH} 7.0)$ with $0.1 \mathrm{mM}$ EDTA, $0.5 \mathrm{mM}$ ascorbate, $0.1 \mathrm{mM} \mathrm{H}_{2} \mathrm{O}_{2}$ and $0.1 \mathrm{ml}$ of enzyme extract. The absorbance of the activity was measured at $290 \mathrm{~nm}$. For the calculation, the extinction coefficient of $2.8 \mathrm{mM}^{-1} \mathrm{~cm}$ was used.

Catalase (EC 1.11.1.6) enzyme activity was performed, followed by Chandlee and Scandalios (1984) using a reaction mixture containing $0.1 \mathrm{M}$ phosphate buffer, $100 \mathrm{mM} \mathrm{H}_{2} \mathrm{O}_{2}$. The reaction mixture was centrifuged at 10,000 rpm for $20 \mathrm{~min}$ at $4 \mathbb{}$ C. The absorbance was measured at $240 \mathrm{~nm}$.

Glutathione S-transferase (GST) (EC 2.5.1.13) activity was estimated, according to Habig et al. (1974), using a reaction mixture containing $100 \mathrm{mM}$ potassium phosphate buffer (pH 7.5) with $1 \mathrm{mM}$ CDNB (1chloro, 2,4 dinitrobenzene), $10 \mathrm{mM} \mathrm{GSH}$ (reduced), and $0.8 \mathrm{ml}$ of enzyme extract. The reaction mixture was incubated for $5 \mathrm{~min}$. The absorbance was measured at $340 \mathrm{~nm}$ for $2 \mathrm{~min}$ at $15 \mathrm{sec}$ time interval.

The estimation of monodehydroascorbate reductase (MDHAR) (EC 1.6.5.4) was followed according to Vanacker et al. (1988). The reaction mixture consists of $100 \mathrm{mM}$ potassium phosphate buffer (pH 7.5), Lascorbic acid $(25 \mathrm{mM})$ and $\mathrm{NADH}(0.2 \mathrm{mM})$. The absorbance was measured at $340 \mathrm{~nm}$ for $2 \mathrm{~min}$ at 15 sec time interval.

\subsection{Measurement of physiological parameters}

Various physiological parameters were measured of transgenic chickpea plants expressing CAMTA1 gene along with treated and untreated control plants. The water use efficiency (WUE), net photosynthetic 
rate $\left(P_{N}\right)$, stomatal conductance $(\mathrm{gs})$, transpiration $(\mathrm{E}), \mathrm{Fv} / \mathrm{Fm}$ (variable to maximum fluorescence) proportion, qP (photochemical quenching), NPQ (non-photochemical quenching), and ETR (electron transport rate) were recorded in entirely open leaves with a photosynthetic system, Li-6400 (LI-COR, USA). The level of $\mathrm{CO}_{2}$ in the leaf chamber was retained at $400 \mu \mathrm{mol}\left(\mathrm{CO}_{2}\right) \mathrm{mol}^{-1}$ air. The photosynthetic photon flux density (PPFD) was retained at $300 \mu \mathrm{mol}$ (photons) $\mathrm{m}^{-2} \mathrm{~s}^{-1}$. The level of VPD (vapor pressure deficit) was lower than $2 \mathrm{kPa}$. The leaf temperature was at $25 \mathbb{\triangle C}$, and $\mathrm{RH}$ (relative humidity) was 55-60\%. All the physiological parameters were recorded between 08:00 to 11:00 h.

\subsection{Statistical analysis}

All the values reported in this work are the means of three replicates. Standard errors were calculated using the means of three replicates. The data were analyzed using DMRT (Duncan's Multiple Range Test) for the analysis of the significant difference between the means $(p<0.05)$.

\section{Results}

\subsection{Screening of transgenic events with PCR}

PCR analysis of the putative transformants expressing the CAMTA1 gene was performed along with the treated and untreated control plants. A specific set of primers were used for the analysis of transgenic chickpea plants. The desired band obtained from the internal set of primers was a $800 \mathrm{bp}$ amplicon, while control plants showed no amplification.

\subsection{Relative expression analysis of CAMTA1 gene by qRT- PCR}

The relative expression of the CAMTA1 gene was analyzed by qRT-PCR with gene-specific primers and, Chickpea actin primer was taken as an endogenous control. The result showed a higher transcript level ranging from 11 to 15 fold change under drought stress (Fig. 1).

The putative transformed chickpea plants were subjected to drought and salinity stress. The plants showed enhanced growth as compared to treated control and wild-type plants (Fig. 2). After 7 days of drought treatment in chickpea, the transgenic plants expressing CAMTA1 gene recovered under wellwatered conditions.

\subsection{Physiological performance of CAMTA1 gene under drought stress and salinity}

Various physiological parameters have been investigated, which showed enhanced expression of CAMTA1 gene against drought as well as in salinity. Net photosynthesis $\left(\mathrm{P}_{\mathrm{N}}: \mu \mathrm{mol} \mathrm{CO}_{2} \mathrm{~m}^{-2} \mathrm{~s}^{-1}\right)$ of CAMTA1 under drought and salinity were enhanced compared with WT plants. The highest activity was observed to be $5 \mu \mathrm{mol} \mathrm{CO} \mathrm{Cm}^{-2} \mathrm{~s}^{-1}$ in (T-5) event under drought and salinity (Fig. 3a and b). 
The transpiration rate $(\mathrm{E})$ was enhanced in transgenic events harbouring the CAMTA1 gene compared to WT plants. The highest activity observed was to be $1.2 \mathrm{mmol} \mathrm{H}_{2} \mathrm{O} \mathrm{m}^{-2} \mathrm{~s}^{-1}$ in (T-2) event in drought and $0.9 \mathrm{mmol} \mathrm{H}_{2} \mathrm{O} \mathrm{m}^{-2} \mathrm{~s}^{-1}$ in (T-5) event under salinity stress (Fig. $3 \mathrm{c}$ and d).

The stomatal conductance $\left(\mathrm{g}_{\mathrm{s}}\right)$ was highest in T-2 and T-4 events upto $0.048 \mathrm{~mol} \mathrm{~m}^{-2} \mathrm{~s}^{-1}$ as compared to wild-type plants and was found to be $0.035 \mathrm{~mol} \mathrm{~m}^{-2} \mathrm{~s}^{-1}$ under drought stress, while under salinity stress, the highest stomatal conductance observed was $0.045 \mathrm{~mol} \mathrm{~m}^{-2} \mathrm{~s}^{-1}$ in T-5 event, as compared to 0.021 mol $\mathrm{m}^{-2} \mathrm{~s}^{-1}$ in wild-type plants (Fig. 3e and f).

The coefficient of photochemical quenching ( $\mathrm{qP}$ ) was found to be enhanced in all the transgenic events under drought and salinity stress compared to wild-type plants. The non-photochemical quenching (NPQ) was slightly higher in transgenic plants (0.5) than in treated control (0.49) but was higher in wild-type plants $(0.65)$ both in drought as well as in salinity stress conditions (Fig. $3 g$ and $\mathrm{h}$ ).

The expression of electron transport rate (ETR) was higher in transgenic (T-5) event and was found to be $70 \mu \mathrm{mol} \mathrm{e}-\mathrm{m}^{-2} \mathrm{~s}^{-1}$ as compared to treated control plants and was observed to be $56 \mu \mathrm{mol} \mathrm{e}-\mathrm{m}^{-2} \mathrm{~s}^{-1}$, and a slight increase of $95 \mu \mathrm{mol} \mathrm{e}-\mathrm{m}^{-2} \mathrm{~s}^{-1}$ in wild-type plants under drought stress. Under salinity stress conditions, the expression of transgenic events was slightly higher as compared to treated control plants than in wild-type plants (Fig. 3i and j).

\subsection{Biochemical analysis of CAMTA1 gene under drought and salinity}

However, various biochemical parameters were also investigated for the expression of the CAMTA1 gene in chickpea both in drought and salinity stress. In our study, the expression of ascorbate peroxidase (APX) was higher in the transgenic lines $11.05 \mu \mathrm{mol} \mathrm{min}^{-1} \mathrm{mg}^{-1} \mathrm{P}^{-1}$ ( $\mathrm{T}-2$ line) as compared to treated control plants which were observed to be $7.50 \mu \mathrm{mol} \mathrm{min}^{-1} \mathrm{mg}^{-1} \mathrm{P}^{-1}$ under drought stress, while in salinity, the expression of APX was found to be higher $10 \mu \mathrm{mol} \mathrm{min}{ }^{-1} \mathrm{mg}^{-1} \mathrm{P}^{-1}$ in T-1 line and $7.5 \mu \mathrm{mol} \mathrm{min}-1 \mathrm{mg}^{-1}$ $\mathrm{P}^{-1}$ in treated control plants (Fig. $4 \mathrm{a}$ and b).

The activity of catalase (CAT) enzyme was shown to be higher at $7 \mu \mathrm{mol} \mathrm{min}^{-1} \mathrm{mg}^{-1} \mathrm{P}^{-1}$ in T-4 line as compared to $4.50 \mu \mathrm{mol} \mathrm{min}{ }^{-1} \mathrm{mg}^{-1} \mathrm{P}^{-1}$ in the treated control plants under drought stress. Under salinity stress, the expression of CAT was higher $7.5 \mu \mathrm{mol} \mathrm{min}{ }^{-1} \mathrm{mg}^{-1} \mathrm{P}^{-1}$ in T-4 line while it was $3.50 \mu \mathrm{mol}$ $\mathrm{min}^{-1} \mathrm{mg}^{-1} \mathrm{P}^{-1}$ in treated control plants (Fig. $4 \mathrm{c}$ and d).

The activity of glutathione-S-transferase (GST) was found to be enhanced by $9 \mu \mathrm{mol} \mathrm{min}^{-1} \mathrm{mg}^{-1} \mathrm{P}^{-1}$ in the $\mathrm{T}-1$ line while it was found to be $3 \mu \mathrm{mol} \mathrm{min}{ }^{-1} \mathrm{mg}^{-1} \mathrm{P}^{-1}$ in treated control plants under drought and salinity stress (Fig. $4 e$ and f).

The total protein content was also found to be enhanced by $4.5 \mathrm{mg} \mathrm{g}^{-1} \mathrm{FW}$ in the T-3 line, as compared to $4.25 \mathrm{mg} \mathrm{g}^{-1} \mathrm{FW}$ in treated control and $3 \mathrm{mg} \mathrm{g}^{-1} \mathrm{FW}$ in wild-type (WT) plants under drought and salinity 
stress (Fig. $4 g$ and $h$ ).

The activity of superoxide dismutase (SOD) was found to be enhanced as $6.5 \mathrm{U} \mathrm{mg}^{-1} \mathrm{P}^{-1}$ in T-4 line, as compared to treated control which was found to be $4.5 \mathrm{U} \mathrm{mg}^{-1} \mathrm{P}^{-1}$ under drought stress, while in salinity, the expression was found to be increased as $6 \mathrm{U} \mathrm{mg}^{-1} \mathrm{P}^{-1}$ in $\mathrm{T}-2$ line as compared to treated control which was found to be $4 \mathrm{U} \mathrm{mg}^{-1} \mathrm{P}^{-1}$ (Fig. $4 \mathrm{i}$ and j).

The activity of monodehydroascorbate reductase (MDHAR) was also found to be higher as $2 \mu \mathrm{mol} \mathrm{min}^{-1}$ $\mathrm{mg}^{-1} \mathrm{P}^{-1}$ in T-1 line as compared to treated control and was found to be $0.9 \mu \mathrm{mol} \mathrm{min}^{-1} \mathrm{mg}^{-1} \mathrm{P}^{-1}$ under drought stress; while under salinity stress, the expression was higher upto $1.6 \mu \mathrm{mol} \mathrm{min}^{-1} \mathrm{mg}^{-1} \mathrm{P}^{-1}$ in T4 line as compared to $0.7 \mu \mathrm{mol} \mathrm{min}{ }^{-1} \mathrm{mg}^{-1} \mathrm{P}^{-1}$ in the treated control (Fig. $4 \mathrm{k}$ and I).

The activity of thiobarbituric acid (TBARS) was also investigated under drought and salinity stress. TBARS was found to be $4.5 \mu \mathrm{mol} \mathrm{g}{ }^{-1} \mathrm{FW}$ in T-4 line and $5.5 \mu \mathrm{mol} \mathrm{g}{ }^{-1} \mathrm{FW}$ as compared to treated control plants under drought stress, while in salinity, the expression of TBARS was found to be $2.5 \mu \mathrm{mol} \mathrm{g}{ }^{-1} \mathrm{FW}$ in $\mathrm{T}-3$ line and $4 \mu \mathrm{mol} \mathrm{g}{ }^{-1} \mathrm{FW}$ in treated control plants (Fig. 5a and b).

The expression of hydrogen peroxide $\left(\mathrm{H}_{2} \mathrm{O}_{2}\right)$ was also studied under drought and salinity stress. The expression was higher in all the transgenic lines and was found to be $2.5 \mu \mathrm{mol} \mathrm{g}{ }^{-1} \mathrm{FW}$ in T-5 line and 3.1 $\mu \mathrm{mol} \mathrm{g}{ }^{-1} \mathrm{FW}$ in control plants under drought stress, while in salinity, the expression was higher as 2.5 $\mu \mathrm{mol} \mathrm{g}{ }^{-1} \mathrm{FW}$ in T-3 line as compared to $4 \mu \mathrm{mol} \mathrm{g}^{-1} \mathrm{FW}$ in control plants (Fig. $5 \mathrm{c}$ and d).

The antioxidant enzymes such as APX, CAT, GST, SOD, MDHAR increases under drought and salinity stress (Kumar et al. 2021). All the above parameters suggested that the CAMTA1 gene enhances antioxidant enzymes activities and protects plants under drought and salinity stress.

\section{Discussion}

Many studies have shown that the CAMTA1 transcription factor plays a vital role in drought tolerance in plants. In Arabidopsis, the mechanism of CAMTA1 TF has been well established. CAMTA1, upon binding with the promoter of the cis-acting element, undergoes a conformational change and activates other stress-responsive genes under various abiotic stress (Pandey et al. 2013), but various roles of CAMTA1 are still to be explored. To explore the role of CAMTA1 gene in chickpea, a tolerant variety of P-362 has been used to analyze various stress-responsive parameters subjected to drought and salinity stress.

Under stress conditions, plants produce reactive oxygen species, which is very harmful to plant growth and induces oxidative stress by generating ROS such as superoxide radicals, hydroxyl radicals, hydrogen peroxide, and alkoxy radicals (Munne-Bosch and Penuelas 2003; Esfandiari et al. 2008). However, various biochemical parameters were also investigated for the expression of the CAMTA1 gene in chickpea under drought and salinity stress. The expression of SOD was found to be higher in all the transgenic plants as compared to treated control plants. The activity of APX is also enhanced in all the transgenic lines 
compared to treated control plants, as APX scavenges peroxides by converting ascorbic acid and helps in the elimination of toxic $\mathrm{H}_{2} \mathrm{O}_{2}$ from plants.

Catalase is also one of the crucial antioxidant enzymes involved in regulating the intracellular level of $\mathrm{H}_{2} \mathrm{O}_{2}$ (Prasad et al. 1995). It converts $\mathrm{H}_{2} \mathrm{O}_{2}$ into $\mathrm{H}_{2} \mathrm{O}$ with the regeneration of $\mathrm{NADP}^{+}$, hence plays an important role in stress conditions (Jimenez et al. 1998). In this study, catalase activity was found to be increased in all the transgenic lines compared to treated control plants.

The increased level of ROS causes oxidative stress to biomolecules such as nucleic acid, lipids, and proteins (Mittler 2002). Among ROS, hydrogen peroxide is a toxic compound and is highly injurious to plants resulting in lipid peroxidation and membrane injury (Sairam et al. 1998; Baisak et al. 1994; Menconi et al. 1995). Hence, the activity of $\mathrm{H}_{2} \mathrm{O}_{2}$ was found to be lowered in all the transgenic lines compared to treated control plants that provide tolerance against stress conditions.

Glutathione S-transferase (GST) is known to express at different stages of plant development. It conjugates GSH to an array of electrophilic compounds of exogenous and endogenous origins (Cummins et al. 2011). GST activity was enhanced in all the transgenic lines compared to treated control plants that provide tolerance against stress.

The activity of monodehydroascorbate reductase (MDHAR) was also enhanced in all the transgenic lines compared to treated control plants. One of the main cellular components that is damaged by ROS are lipids (peroxidation of unsaturated fatty acid). TBARS is widely used as an oxidative marker, that is formed when there is an increase in lipid peroxidation and causes cellular damage and toxicity. The expression of TBARS was found to be lower in all the transgenic lines as compared to treated control plants. The results showed that the lower value of TBARS causes less toxicity against stress conditions.

The physiological parameters were also investigated of the CAMTA1 gene both in the drought and salinity stress. Drought stress is one of the most important limiting factors which limits plant growth and productivity. It affects both elongation and expansion (Anjum et al. 2003a; Bhatt and Srinivasa Rao 2005; Kusaka et al. 2005; Shao et al. 2008). It also affects plant water relations, due to which there is a decrease in carbon assimilation and results in an imbalance between electron excitation, hence results in the production of ROS (Abid et al. 2018). Due to the closing of stomata under drought stress, there is a decrease in the $\mathrm{CO}_{2}$ fixation and reduces transpiration rate. In our study, the net photosynthesis $\left(P_{N}\right)$ showed enhanced expression of the CAMTA1 gene in all the transgenic events (T-1 to T-6) as compared to a slight decrease in wild-type plants during drought and salinity stress. Transpiration rate and stomatal conductance are also enhanced in all the transgenic events as compared to wild-type plants in drought and salinity stress. Photochemical quenching (qP) was higher in all the transgenic events as compared to wild-type plants and a slight decrease in treated control plants in drought and salinity stress. The nonphotochemical quenching $(\mathrm{qN})$ has a protective role in oxidative stress. The expression of the CAMTA1 gene in non-photochemical quenching was slightly higher in transgenic events as compared to treated control in drought and salinity stress. Due to the over-excitation of photosystem II, the electron transport 
rate increases, which leads to heat consumption, and hence there is a decrease in photosynthetic rate. The expression of ETR in the transgenic plants was higher as compared to treated control plants, while a slight decrease in untreated control plants.

We hypothesize that CAMTA1 acts as a positive regulator under drought and salinity stress based on our investigations. The parameters mentioned above showed enhanced expression in the transgenic events as compared to wild-type plants. Under drought and salt stress, the CAMTA1 gene plays a protective role which provides plants to withstand tolerance under stress conditions.

\section{Conclusions}

The present study explored the role of the CAMTA1 transcription factor, which has not been investigated in detail concerning its role in both biochemical and physiological parameters. The enhanced expression in all transgenic lines showed that the CAMTA1 gene provides tolerance against drought stress. The reduced stress marker, TBARS, and $\mathrm{H}_{2} \mathrm{O}_{2}$ enhanced the overall performance of the transgenic plants and overcame oxidative stress. The increased level of photosynthesis $\left(P_{N}\right)$, stomatal conductance, and nonphotochemical quenching $(\mathrm{qN})$ enhanced the physiological performance of chickpea under drought and salinity stress. The above result showed that CAMTA1 regulates drought and salinity tolerance in chickpea. The overall study of the CAMTA1 gene can be used to develop tolerant chickpea in arid and semi-arid regions and may prove effective under drought and salinity abiotic stresses.

\section{Declarations}

The authors declare that they have no known competing financial interests.

\section{Acknowledgements}

We thank the Council of Scientific and Industrial Research (CSIR), New Delhi, for funding the research project BSC0204. The authors are also thankful to DST, New Delhi (M) CSIR, New Delhi (AK, AKD) UGC, New Delhi (VK, SN) for providing research fellowships.

\section{Author's contribution}

Meenakshi: Conceptualization, Investigation, Methodology, Validation, Roles/Writing - original draft, Writing - review \& editing, Anil Kumar. Formal analysis, Investigation, Arvind Kumar Dubey: Formal analysis, Varun Kumar. Investigation, Shiv Narayan: Investigation, Samir V. Savant: Supervision, Veena Pande: Supervision, Pramod Arvind Shirke: Formal analysis, Indraneel Sanyal: Funding acquisition, Project administration, Supervision, Writing - review \& editing.

\section{Ethical approval}

This article does not contain any studies with human participants or animals performed by any of the authors. 


\section{Data availability}

All data generated or analysed during this study are included in this published article [and its supplementary information files].

\section{References}

1. Abid M, Ali S, Qi LK, Zahoor R, Tian Z, Jiang D, Snider JL, Dai T (2018) Physiological and biochemical changes during drought and recovery periods at tillering and jointing stages in wheat (Triticum aestivum L.). Sci Rep 8(1):1-15. http://doi.org/10.1038/s41598-018-21441-7

2. Anjum F, Yaseen M, Rasul E, Wahid A, Anjum S (2003) Water stress in Barley (Hordeum vulgare L.). II. Effect on chemical composition and chlorophyll contents. Pak J Agric Sci 40:45-49

3. Kumar A, Kumar V, Dubey AK, Ansari MA, Narayan S, Meenakshi, Kumar S, Pandey V, Pande V, Sanyal I (2021) Chickpea glutaredoxin (CaGrx) gene mitigates drought and salinity stress by modulating the physiological performance and antioxidant defense mechanisms. Physiol Mol Biol Plants 27(5):923-944

4. Baisak R, Rana D, Acharya PB, Kar M (1994) Alterations in the activities of active oxygen scavenging enzymes of wheat leaves subjected to water stress. Plant Cell Physiol 35(3):489-495. https://doi.org/10.1093/oxfordjournals.pcp.a078620

5. Bhatt RM, Rao NS (2005) Influence of pod load on response of okra to water stress. Ind J Plant Physiol 10(1):54

6. Beauchamp C, Fridovich I (1971) Superoxide dismutase: improved assays and an assay applicable to acrylamide gels. Anal Biochem 44(1):276-287. https://doi.org/10.1016/0003-2697(71)90370-8

7. Bradford MM (1976) A rapid and sensitive method for the quantitation of microgram quantities of protein utilizing the principle of protein-dye binding. Anal Biochem 72(1-2):248-254. https://doi.org/10.1016/0003-2697(76)90527-3

8. Chandlee JM, Scandalios JG (1984) Analysis of variants affecting the catalase developmental program in maize scutellum. Theor Appl Genet 69(1):71-77. http://doi.org/10.1007/bf00262543

9. Cummins I, Dixon DP, Freitag-Pohl S, Skipsey M, Edwards R (2011) Multiple roles for plant glutathione transferases in xenobiotic detoxification. Drug Metabolism Rev 43(2):266-280. https://doi.org/10.3109/03602532.2011.552910

10. Esfandiari E, Shakiba MR, Mahboob SA, Alyari H, Shahabivand S (2008) The effect of water stress on the antioxidant content, protective enzyme activities, proline content and lipid peroxidation in wheat seedling. Pak J Biol Sci: PJBS 11(15):1916-1922.

http://doi.org/10.3923/pjbs.2008.1916.1922

11. Farooq M, Wahid A, Kobayashi N, Fujita DBSMA, Basra SMA (2009) Plant drought stress: effects, mechanisms and management. In: Sustainable Agriculture. Springer, Dordrecht, pp 153-188. http://doi.org/10.1007/978-90-481-2666-8_12 
12. Galon Y, Finkler A, Fromm H (2010) Calcium-regulated transcription in plants. Mol Plant 3(4):653669. https://doi.org/10.1093/mp/ssq019

13. Gaur PM, Krishnamurthy L, Kashiwagi J (2008) Improving drought-avoidance root traits in chickpea (Cicer arietinum L.) - Current status of research at ICRISAT. Plant Production Sci 11(1):3-11. https://doi.org/10.1626/pps.11.3

14. Habig WH, Pabst MJ, Jakoby WB (1974) Glutathione S-transferases: the first enzymatic step in mercapturic acid formation. J Biol Chem 249(22):7130-7139. https://doi.org/10.1016/S00219258(19)42083-8

15. Jaleel CA, Manivannan Paramasivam, Wahid A, Farooq M, Al-Juburi HJ, Ramamurthy S, Panneerselvam R (2009) Drought stress in plants: a review on morphological characteristics and pigments composition. Int J Agric Biol 11(1):100-105

16. Jimenez A, Hernandez JA, del Río LA, Sevilla F (1997) Evidence for the presence of the ascorbateglutathione cycle in mitochondria and peroxisomes of pea leaves. Plant Physiol 114(1):275-284. https://doi.org/10.1104/pp.114.1.275

17. Kusaka M, Ohta M, Fujimura T (2005) Contribution of inorganic components to osmotic adjustment and leaf folding for drought tolerance in pearl millet. Physiol Plant 125(4):474-489. https://doi.org/10.1111/j.1399-3054.2005.00578.x

18. Livak KJ, Schmittgen TD (2001) Analysis of relative gene expression data using real-time quantitative PCR and the $2-\Delta \Delta$ CT method. Methods 25(4):402-408. https://doi.org/10.1006/meth.2001.1262

19. Menconi MCLM, Sgherri CLM, Pinzino C, Navari-Lzzo F (1995) Activated oxygen production and detoxification in wheat plants subjected to a water deficit programme. J Exp Bot 46(9):1123-1130. https://doi.org/10.1093/jxb/46.9.1123

20. Munne-Bosch S, Penuelas J (2003) Photo-and antioxidative protection, and a role for salicylic acid during drought and recovery in field-grown Phillyrea angustifolia plants. Planta 217(5):758-766. http://doi.org/ 10.1007/s00425-003-1037-0

21. Mittler R (2002) Oxidative stress, antioxidants and stress tolerance. Trends Plant Sci 7(9):405-410. https://doi.org/10.1016/S1360-1385(02)02312-9

22. Nakano Y, Asada K (1981) Hydrogen peroxide is scavenged by ascorbate-specific peroxidase in spinach chloroplasts. Plant Cell Physiol 22(5):867-880.

https://doi.org/10.1093/oxfordjournals.pcp.a076232

23. Pandey N, Ranjan A, Pant P, Tripathi RK, Ateek F, Pandey HP, Patre UV, Sawant SV (2013) CAMTA 1 regulates drought responses in Arabidopsis thaliana. BMC Genom 14(1):1-23. http://doi.org/10.1186/1471/-2164-14-216

24. Prasad TK, Anderson MD, Stewart CR (1995) Localization and characterization of peroxidases in the mitochondria of chilling-acclimated maize seedlings. Plant Physiol 108(4):1597-1605. https://doi.org/10.1104/pp.108.4.1597 
25. Poovaiah BW, Du L, Wang H, Yang T (2013) Recent advances in calcium/calmodulin-mediated signaling with an emphasis on plant-microbe interactions. Plant Physiol 163(2):531-542. https://doi.org/10.1104/pp.113.220780

26. Rao LS, Rani PU, Deshmukh PS, Kumar PA, Panguluri SK (2007) RAPD and ISSR fingerprinting in cultivated chickpea (Cicer arietinum L.) and its wild progenitor Cicer reticulatum Ladizinsky. Genetic Resources Crop Evol 54(6):1235-1244. http://doi.org/ 10.1007/s10722-006-9104-6

27. Sairam RK, Deshmukh PS, Saxena DC (1998) Role of antioxidant systems in wheat genotypes tolerance to water stress. Biol Plant 41(3):387-394

28. Shao HB, Chu LY, Shao MA, Jaleel CA, Hong-mei M (2008) Higher plant antioxidants and redox signaling under environmental stresses. CR Biol 331(6):433-441.

https://doi.org/10.1016/j.crvi.2008.03.011

29. Vanacker H, Harbinson J, Ruisch J, Carver TLW, Foyer CH (1998) Antioxidant defences of the apoplast. Protoplasma 205(1):129-140

\section{Figures}

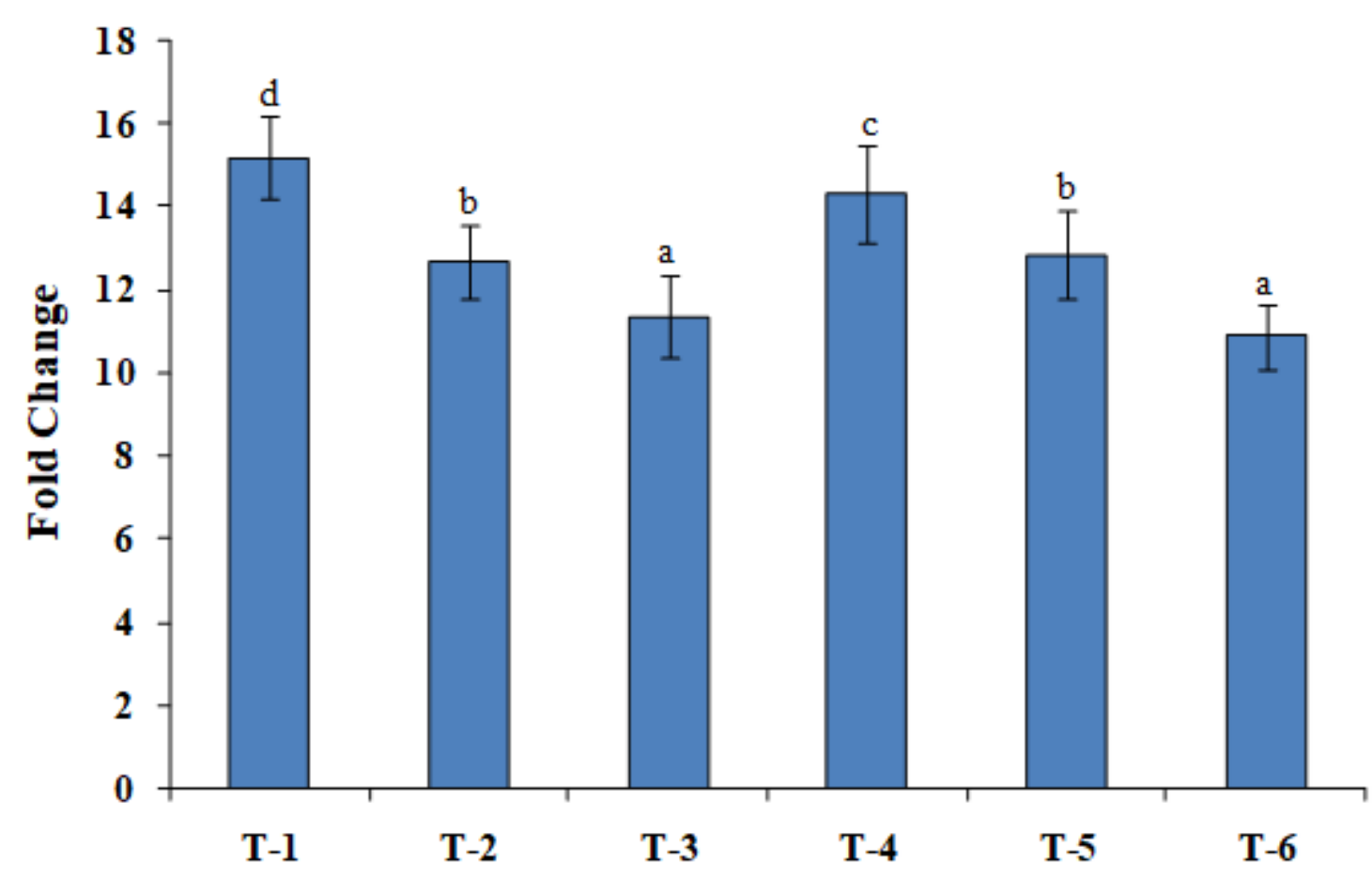

Figure 1

Relative expression of CAMTA1 gene in transgenic chickpea plants by qRT-PCR analysis. 
a
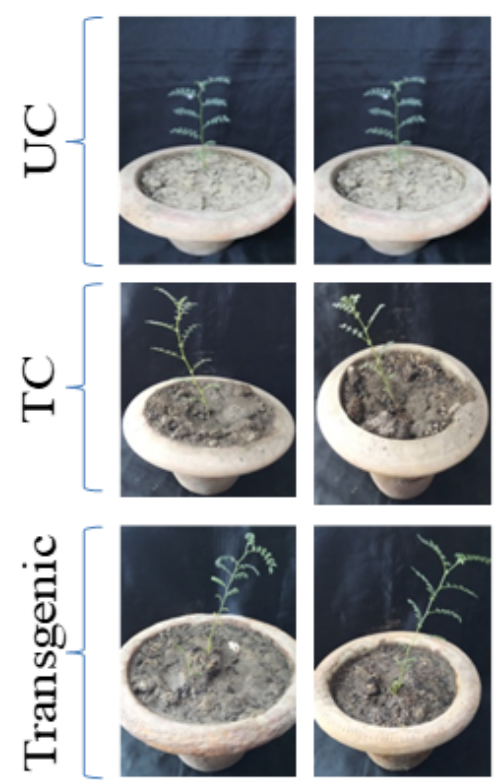

0 day b
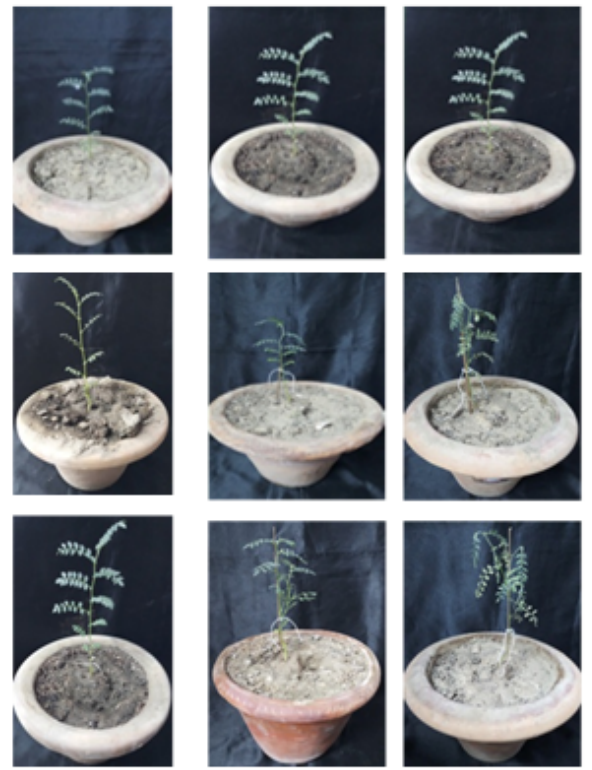

Drought
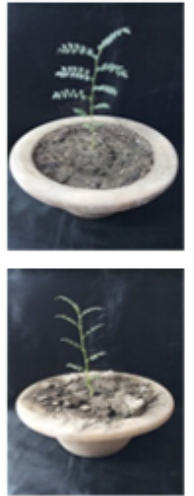

c
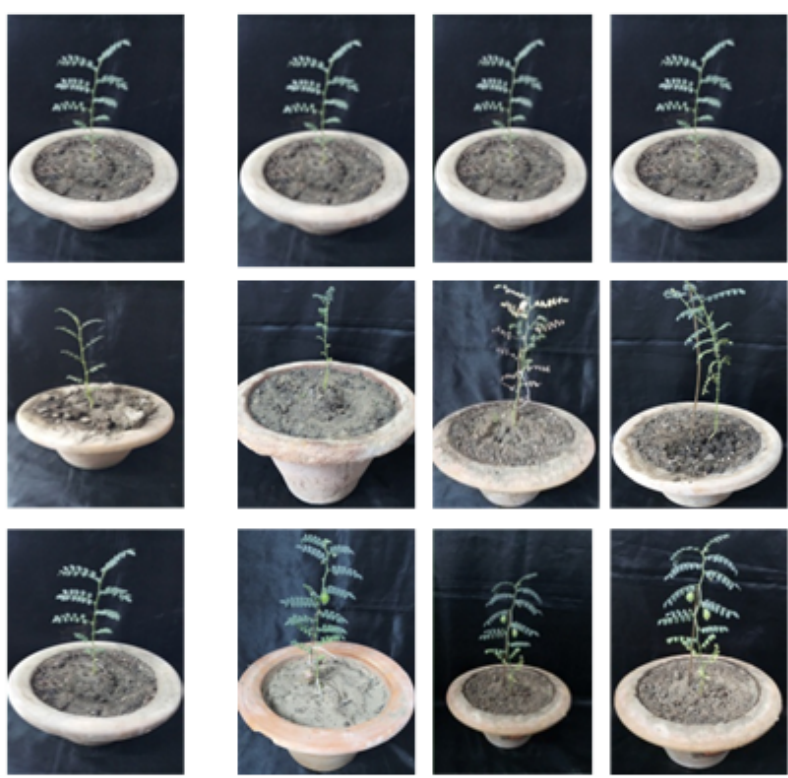

$60 \mathrm{mM} \mathrm{NaCl}$

Figure 2

Morphological appearance of chickpea plants under drought and salinity stress. a After 7 days of drought treatment. b salinity stress by $60 \mathrm{mM} \mathrm{NaCl}$. c transgenic plants expressing CAMTA1 gene recovered well as compared to wild-type plants under well watered conditions. 

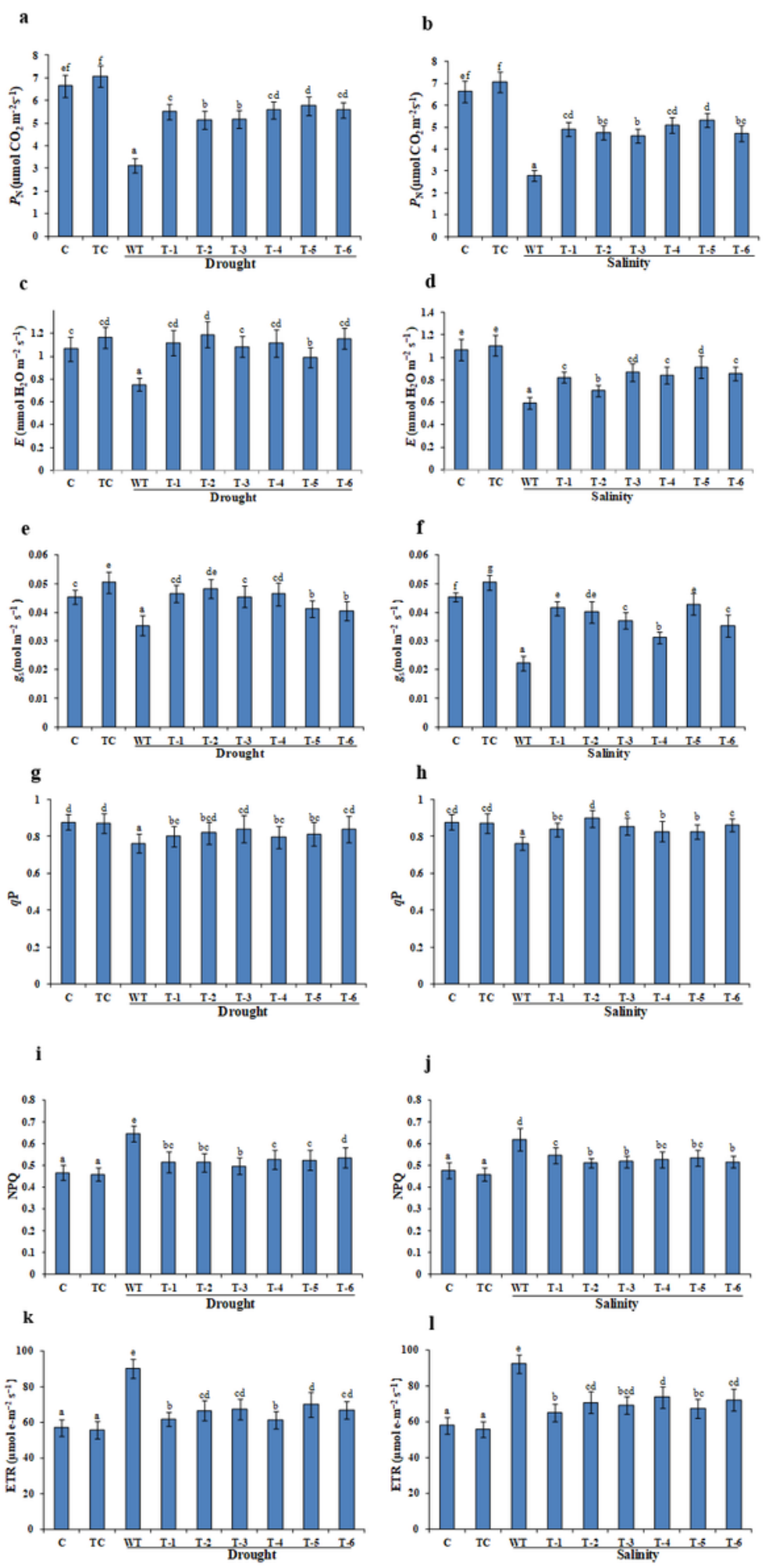

Figure 3

Physiological performances of CAMTA1 gene in chickpea against drought and salinity stress. $a$ and $b$ represents photosynthesis (PN). $c$ and $d$ represents transpiration rate (E). e and $f$ represents stomatal conductance (gs). $g$ and $h$ represents photochemical quenching (qP). $i$ and $j$ represents nonphotochemical quenching (NPQ). $k$ and I electron transport rate (ETR). Duncan's Multiple Range Test 
(DMRT) was used for the analysis of significant difference between the mean $(p<0.05)$ has been compared. All the values are the means of three replicates \pm SD.
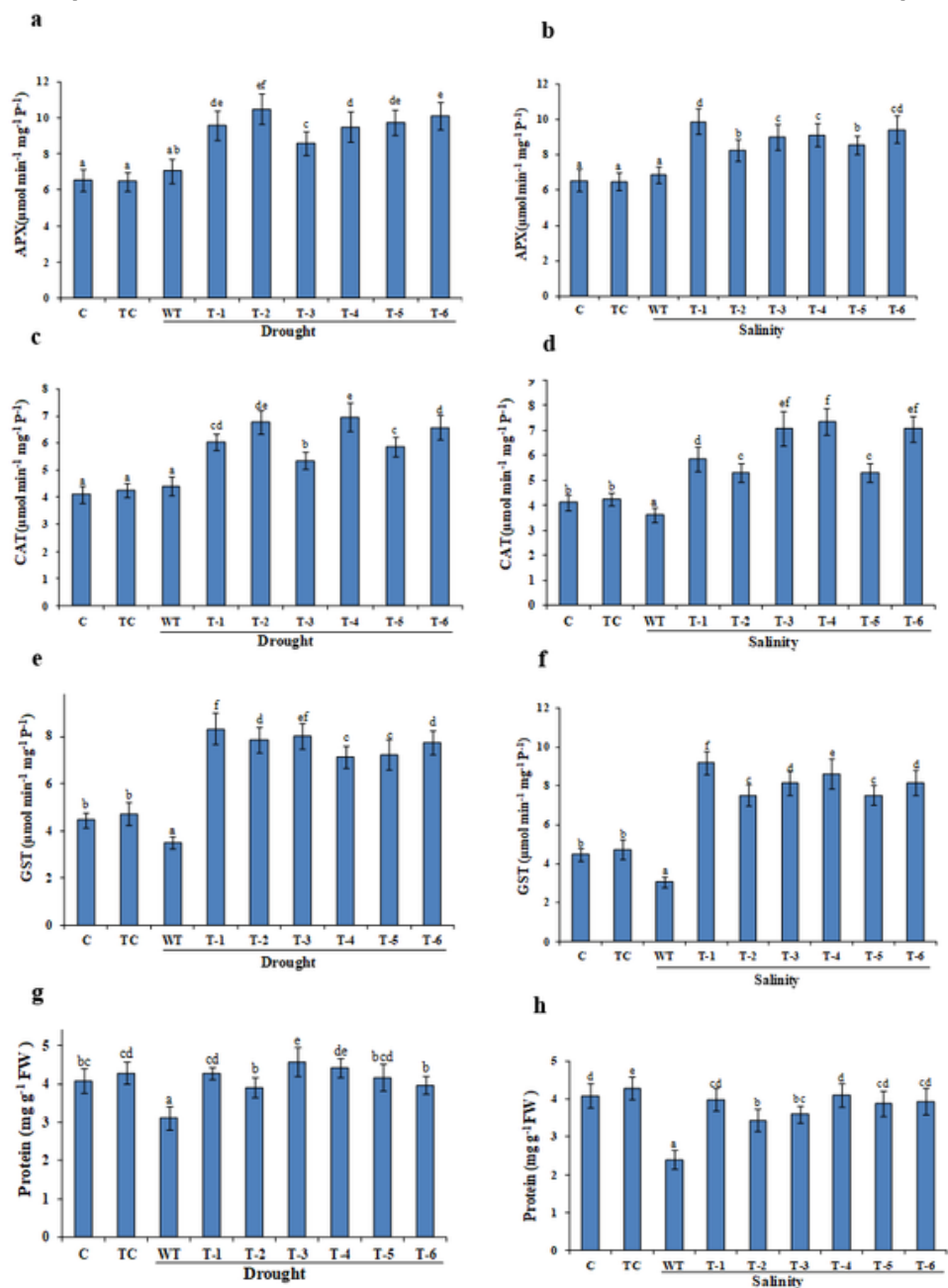

h
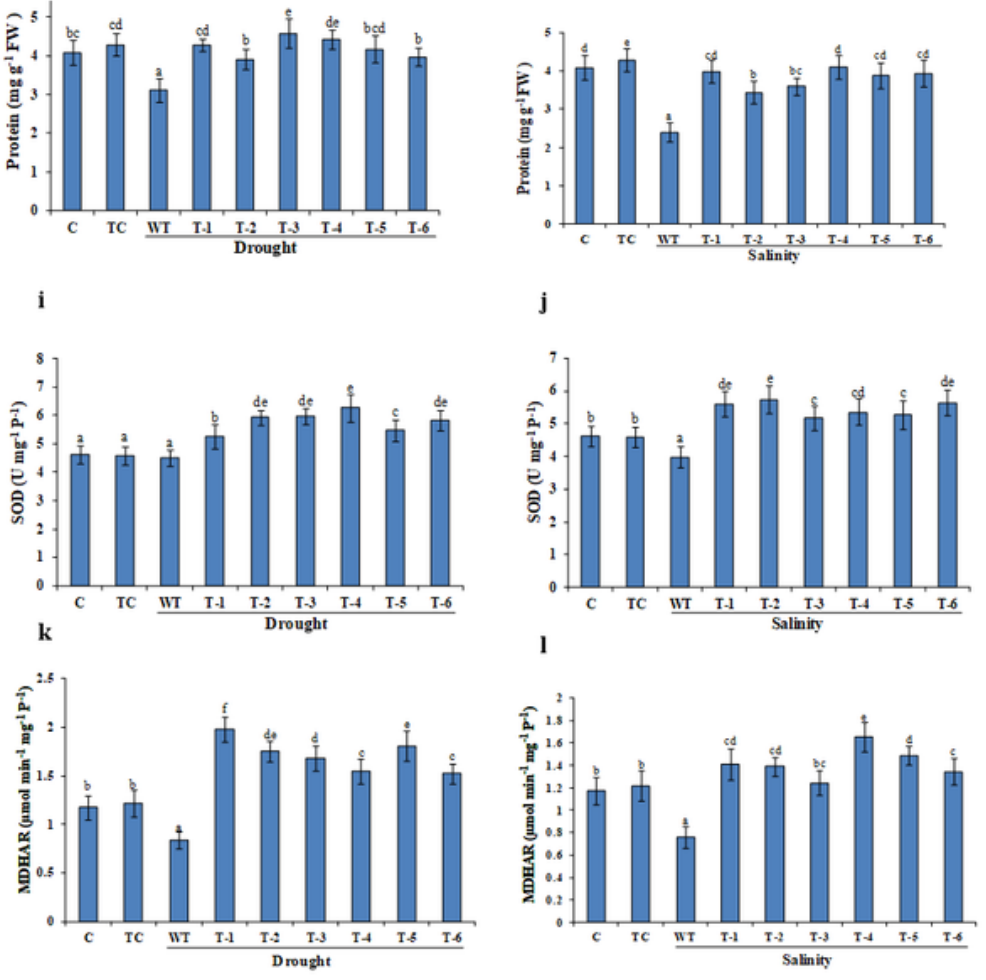

Figure 4

The level of antioxidant enzymes under drought and salinity stress. $a$ and $b$ represents ascorbate peroxidase (APX). $c$ and $d$ represents catalase (CAT). e and $f$ represents glutathione S-transferase (GST). $\mathrm{g}$ and $\mathrm{h}$ represents protein estimation of CAMTA1 gene. $\mathrm{i}$ and $\mathrm{j}$ represents superoxide dismutase (SOD). $\mathrm{k}$ 
and I represents monodehydoascorbate reductase (MDHAR) showed enhanced expression of transgenic lines as compared to Treated Control (TC) and Wild-Type (WT) plants. Duncan's Multiple Range Test (DMRT) was used for the analysis of significant difference between the mean $(p<0.05)$ has been compared. All the values are the means of three replicates \pm SD.

a

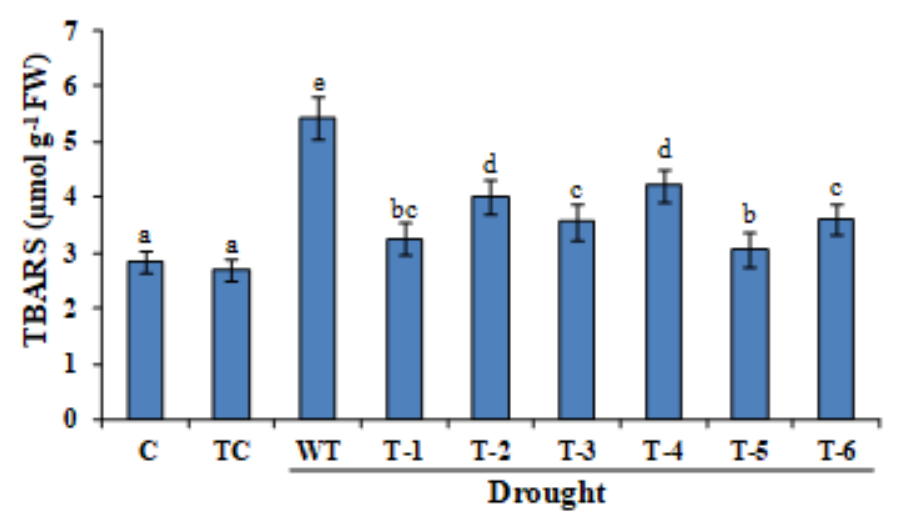

\section{c}

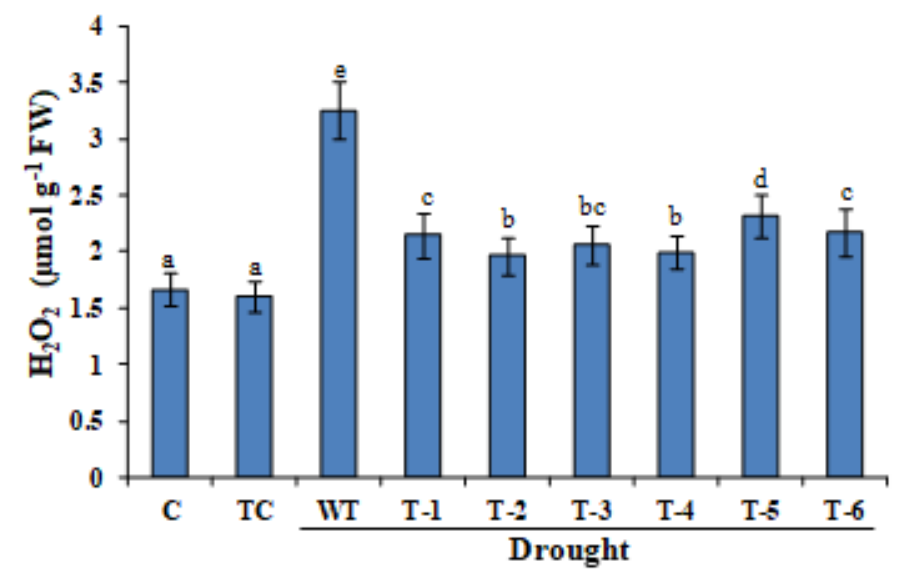

b

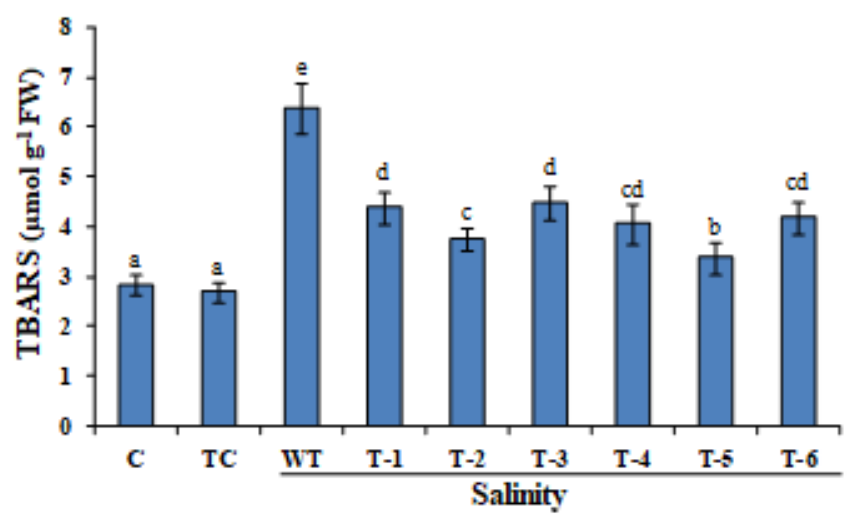

d

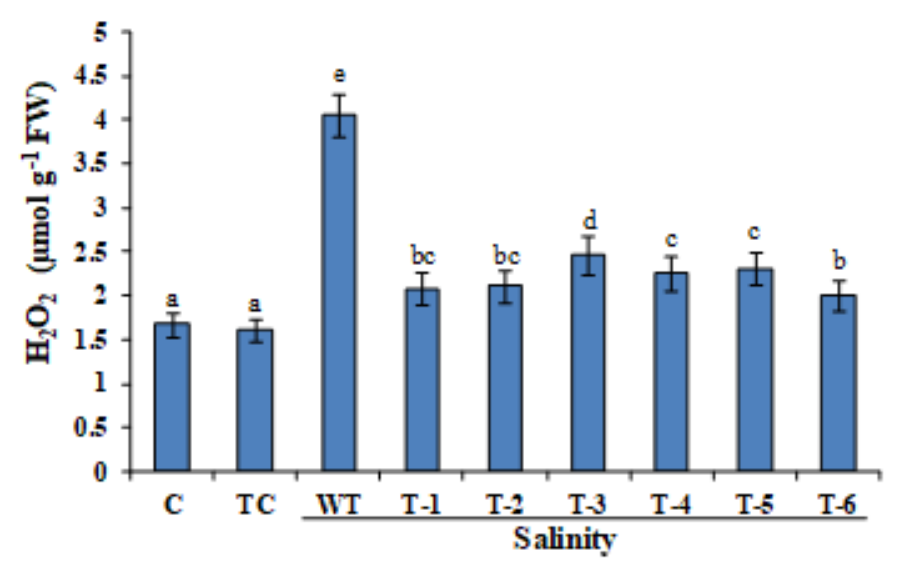

Figure 5

The level of stress markers under drought and salinity stress. a and b TBARS was found to be low as compared to treated control and wild type plants. $\mathrm{c}$ and d the level of $\mathrm{H} 2 \mathrm{O} 2$ was also found to be less as compared to Treated Control (TC) and Wild-Type (WT) plants. Duncan's Multiple Range Test (DMRT) was used for the analysis of significant difference between the mean $(p<0.05)$ has been compared. All the values are the means of three replicates \pm SD.

\section{Supplementary Files}

This is a list of supplementary files associated with this preprint. Click to download.

- Fig.S1schematicrepresentationofCAMTAconstruct.docx 
- Fig.S2Transformationinchickpea.docx 